Jpn. J. Pharm. Health Care Sci.

一般論文 35(5) 325-336 (2009)

\title{
保険薬局薬斉師の治験に関する意識調査
}

- 薬学生との比較-

\author{
有田悦子 ${ }^{* 1,5}$, 飯岡緒美 ${ }^{1}$, 岡本実穂 ${ }^{2}$, 夏目寛子 ${ }^{3}$
}

田村祐輔 ${ }^{4}$, 氏原 淳 $^{5}$, 厚田幸一郎 6

北里大学薬学部薬学教育研究センター医療心理学部門 ${ }^{1}$,

龍生堂薬局 ${ }^{2}$, 東邦大学医療センター大橋病院薬斉部 ${ }^{3}$, 株式会社ファーコス ${ }^{4}$, 北里研究所病院臨床試験部 ${ }^{5}$, 北里大学薬学部薬物治療学 $11^{6}$

\section{Survey on Health Insurance \\ Pharmacy Pharmacists Image of Clinical Trials - Comparison with that of Pharmacy Students-}

\author{
Etsuko Arita*1,5, Tomomi lioka', Miho Okamoto ${ }^{2}$, Hiroko Natsume ${ }^{3}$, \\ Yusuke Tamura ${ }^{4}$, Atsushi Ujihara ${ }^{5}$ and Koichiro Atsuda ${ }^{6}$ \\ Department of Medical Psycology, Pharmaceutical Education Research Center, \\ Kitasato University School of Pharmacy ${ }^{1}$ \\ Ryuseido Pharmacy ${ }^{2}$ \\ Division of Pharmacy, Toho University Medical Center, Ohashi Hospital ${ }^{3}$ \\ Pfercos ${ }^{4}$, Division of Clinical Research, Kitasato Institute Hospital ${ }^{5}$ \\ Department of Hospital Pharmacy, Clinical Pharmacy Research Center, \\ Kitasato University School of Pharmacy ${ }^{6}$ \\ $\left[\begin{array}{l}\text { Received September 11, } 2008 \\ \text { Accepted March 16, } 2009\end{array}\right]$
}

A rapidly growing number of pharmacy graduates have been taking up employment as CRCs (Clinical Research Coordinators). In view of this, we think it is important to ensure that pharmacy students who engage in clinical trial work as a CRC take a curriculum that prepares them well for this profession. This is in keeping with" new five-year plan for clinical trial activation" which states that persons conducting clinical trials should be better qualified.

The curriculum should be improved not only from the point of view of the knowledge provided but also by including practical training in clinical trials in order to prepare students for their future work as a pharmacist by ensuring that they have a correct understanding of clinical trials. In order to make the part of the pharmacy curriculum on clinical trials more useful to students, we investigated the image that pharmacy students and health insurance pharmacy pharmacists have of clinical trials as well as clinical trial participation factors.

The pharmacists' image of clinical trials was more negative than that of the students, they had a strong feeling of anxiety towards them, and tended to be passive regarding participation in clinical trials.

We will use these results to examine the pharmacy education program in relation to clinical trials.

Key words — clinical trials, pharmacists, pharmacy students, pharmaceutical education, CRC

緒言

近年, 治験関連業務に就く薬学卒業生や, 病院等の医 療機関で CRC(Clinical Research Coordinator)として治験 に携わる薬剂師が増えている．との背景として，1997 年より施行された新 $\operatorname{GCP}($ 医薬品の臨床試験実施基準及
び炎の関連通知 $)^{1} に$ に, 薬剂師が「治験薬管理者」や「治 験協力者」として治験にかかわることが明記されたこと や，厚生労働省・文部科学省が 2003 年に示した「全国 治験活性化 3 力年計画」などの影響が考えられる .

また，2007 年 3 月には, 文部科学省・厚生労働省よ

り「新たな治験活性化 5 力年計画」3゙が出され, 平成 23 年度までに実施予定のアクションプラン「(2)治験・臨床 
研究を実施する人材の確保」の中で, 「薬斉師, 看護師, 臨床検查技師等の治験・臨床研究, 生物統計, 研究倫理 に係る内容についての教育を充実させ , 国家試験の出題 基準に収載する等により，治験・臨床研究についての理 解を充実させる」ことが明記されており，大学教育の中 での治験教育に期待がけりれている．

薬学教育は 2006 年度より 6 年制となったが, 新しい モデル・コアカリキュラムでは治験に関する項目もあげ られている. 光れに伴い, 本学においても病院実習の一 環として治験教育を導入し，講義のみならず同意説明の ロールプレイなどを実施している4).

従来, 治験実施機関はある程度の規模の大きい病院が 中心であり，治験業務に携わる薬斉師も病院勤務薬剂師 が中心であったが, 現在は地域のクリニックと連携して 治験を実施するケースや CRC 業務を併設する薬局も増 えており，今後保険薬局の密口で台験に関する相談か増 えていくことが予想される .

治験をめぐる国の方針や教育システムの変化は激しい 一方で, 実際に患者からの相談を受ける可能性のある保 険薬局の薬剂師が治験についてどのような認識や知識を 持っているのかについては，これまで調査されてこな かった．また，これまで薬学部において治験に関する教 育はあまり重視されておらず，卒業後に治験業務に携わ る機会を持った一部の薬斉師を除いて一般的に治験に関 する認知度は低いことが予想される．乥こで，現場で患 者からの相談を受ける立場として治験にかかわることに なると考えられる保険薬局薬剂師の治験に対する意識や 教育状況を把握し，今後の治験教育プログラム構筑の基 盤とするために本研究を実施した . 対照として, 薬学生 との比較を行うことで, 治験に関する教育状況の変遷を 明らかにすることも目的とした .

\section{方法}

\section{1. 対象およひ調査期間}

本調査は，2007 年 5 月上旬〜 6 月下旬に研究の趣旨を 説明し口頭て調査協力の同意が得られた保険薬局薬剂師 140 名を対象としてアンケート調査を実施し, 回答が得 られた 91名の結果について分析を行った(回収率 65 \%) . また，対照として 2007 年 6 月に調査協力の同意が 得られた本学薬学部 4 年生 272 名にもアンケート調査を 実施し有効回答が得られた 192 名の結果についても分析 を行った(回収率 70\%) .

\section{2. 質問項目}

質問項目は先行研究 ${ }^{5-13}$ を参考に作成し, 項目 I：対 象者背景(性別, 年代, 治験参加の有無, 学生時代の病 院実習経験の有無等)，項目１I：治験に対する意識(治験 への関心，治験に対するイメージ，治験への参加，治験 参加を相談されたときの対応)，項目 IIII：治験に関する
知識や教育状況(治験用語に関する知識，治験に関する 学習機会, 治験に関する情報源), 項目IV : 今後の治験 教育(教育へのニーズ, 薬学教育での治験教育)について 質問した 具体的な質問項目については表 1 にまとめた .

\section{3. 統計解析}

統計解析には SPSS for Windows11.0 皇用い，クロス 表によるPearson のX²検定，Pearson 相関を用いた 。こ の時，有意水準 $5 \%$ 未満を有意差ありとした .

なお, 本研究は北里研究所病院研究倫理委員会の承認 を得て行った。

結果

項目 I：対象者背景

対象者背景については, 表 2 に示した 。

項目 II：治験に対する意識

1. 治験への関心(図 1)

治験への関心が「ある」,「少しある」と答えた割合は， 薬斉師が $74 \%$, 薬学生が $82 \%$ と, 薬阁師は薬学生より も有意に低かった(Pearson の相関 $r=0.152, p<.05)$.

\section{2. 治験に対するイメージ(図 2)}

治験から連想する言葉を選択肢から選んでもらったと ころ, 薬斉師, 薬学生ともに「実験」を選んだ割合が高 かった、「実験」に加え「不安」、「危険」、「閉鎖的」な どどちらかといえばマイナスイメージの言葉を答えた割 合は薬剂師 $48.7 \%$, 薬学生 44.5\%，一方「貢献」,「希 望」,「最新」,「治療」などどちらかといえばプラスイ メージの言葉を答えた割合は薬剤師 $49.1 \%$ ，薬学生 52.9 \%であった .

\section{3. 治験への参加}

1)治験に参加してみたいか(図 3)

治験に「参加したい」,「どちらかといえば参加した い」と答えた割合は, 薬阂師 40\%, 薬学生 62\% と, 薬 学生のほうが有意に高かった(Pearson の相関 $r=0.227$, $\mathrm{p}<0.01)$.

2)治験の参加に不安があるか(図 4)

治験の参加に「不安がある」と答えた割合は薬剂師， 薬学生ともに高く, 特に薬剂師は $97 \%$ が不安を示して いた . 参加に不安があると回答したものを対象に , 具体 的に何に対しての不安かを選択肢の中から複数選んでも らい关の結果を表 3 にまとめた。薬㶡師，薬学生ともに 「副作用」,「健康被害発生時の対応」,「スケジュール」 などをあげる割合が高かった .

3)治験参加のメリットとデメリット(表 4)

治験参加のメリット・デメリットを選択肢の中からー つ選んでもらい关の結果を表 4 にまとめた . 
表 1 ．アンケートの質問項目

\section{項目 II : 治験に対する意識、に関する質問（抜粋）}

・治験と聞いて、連想する言葉はどれですか?最もよくあてはまるものを1つ○で囲んでください。
1) 貢献
2) 希望
3 ) 最新
4) 危険
5) 不安
6) 閉鎖的
7) 治療
8）実験

・(治験に参加を決める際に不安があると答えた人) それは何についての不安ですか? 3つまで○で囲ん でください。

1）通院、検査のスケジュール

2) 副作用

3）治験薬の効き目

4）プラセボ（薬の成分を含まない州薬）に当たる可能性

5）健康被害（副作用など）があったときの対心

6）服用してはいけない薬があるなどのいろいろな制約があること

7）治験をやめたいと思ったときの対心

8) プライバシー

9) その他 (

・治験に参加する一番のメリットは何だと思いますか?最もよくあてはまるものを1つつで囲んでくださ い。
1）社会の役に立つ
2）治療の選択肢が增元る
3）手厚い医療が受けら机る
4）待ち時閒か短くてすむ
5）医療費が少なくてすむ
6）交通費などに対しての協力費がもらえる
7) その他 (

・治験に参加する一番のデメリットは何だと思いますか?最もよくあてはまるものを1つ○で囲んでくだ さい。
1）副作用の心配がある
2）プラセボ (僁薬) を飲む可能性がある
3）定期的に病院に通うことになる
4) 細かい制限が多い
5) プライバシーが心配
6）治験を中止したあとの診療のこと
7) その他
)

・治験に参加するかどうか絁んでいる患者様から相談をされた場合、どのような対応をしますか? 最もよくあ てはまるものを1つ○で囲んでください。
1) 原則として勧める
2）どちらかといえば衔める
3）どちらかといえば彻めない
4）原則として衔めない
・それはなぜですか?

メリットについて検討を行ったところ，薬阂師は薬学 生よりも「治療の選択肢が増える」と答えた割合が有意 に高かった(Pearson のX $\left.{ }^{2}=28.73, p<0.05\right)$.また , メ リットとして「協力費」と答えたのは薬剤師で $1 \%$ だっ たのに対し，薬学生は $24 \%$ と特徵的な傾向を示した .

一方，デメリットは，薬斉師，薬学生ともに「副作用 の心配」が1番多く，「細かい制限が多い」「「定期的に 病院に通う」などが続いていた .

4)治験参加を相談されたときの対応(図 5)

患者や知人から治験への参加を相談されたときの対応 について選択肢から選んでもらったところ図 5 のような 結果になった 、勧める理由を自由に記述してもらったと
ころ，薬斉師は「治療の選択肢が増える」,「悩んでいる ということは患者に参加の意思がみられるため」,「最新 の医療を受けられるチャンス」などをあげ，薬学生は同 じく「治療の選択肢か増える」,「細かく診察・検査して もらえる」,「人の役に立つ」,「最新の医療が受けられる チャンス」などをあげていた .

一方，勧めない理由として，薬剤師は「副作用の心 配」、「自分に十分な知識がないから」、副作用等が生じ た場合責任をとれない」,「決めるのは本人」などを，薬 学生は同樣に「副作用の心配」,「リスクを伴う」,「何か 起こった場合責任を感じる」,「制限が多く大变乥う」, 「自分に十分な知識がないから」などをあげていた . 


\title{
項目 III : 治験の知識と教育機会、に関する質問(抜粋)
}

・治験に関連した以下の言葉の内容をどこまでご存知ですか?以下の言葉を「説明できる」、聞いたことがあ

る」「聞いたことがない」から只選んで［］の中に○をつけてください。

\author{
説明できる 聞いたことがある 聞いたことがない
}

(1) ヘルシンキ宣言

(2) ニュールングベルグ網領

(3) GCP

(4) $\mathrm{ICH}$

(5）インフォーム・ドコンセント

(6) 標准業務于:順書

(7) モニタリング

(8) IRB

(9) $\mathrm{CRC}$

(10) 二重肓検試験

$\begin{array}{llllll}{[} & ] & {[} & ] & {[} & ] \\ {[} & ] & {[} & ] & {[} & ] \\ {[} & ] & {[} & ] & {[} & ] \\ {[} & ] & {[} & ] & {[} & ] \\ {[} & ] & {[} & ] & {[} & ] \\ {[} & ] & {[} & ] & {[} & ] \\ {[} & ] & {[} & ] & {[} & ] \\ {[} & ] & {[} & ] & {[} & ] \\ {[} & ] & {[} & ] & {[} & ] \\ {[} & ] & {[} & ] & {[} & ]\end{array}$

・学生時代、治験について、学ぶ機会がありましたか? 最もよくあてはまるものを1つ○で团んでください。
1) 講義で学んだ
2）実羿で学んだ
3）講義と实習㕯方
4）白主的に勉強したことがある（研究空等を含む）
5) 学んでいない・あるいは覚えていない

・卒業後、治験について、何かを通じて影響を受けたことはありますか？西てはまるものを全て○で团んでく ださい。

1) 新聞・雑誌・テレビなどのマスメディア

2）インターネット 3）病院内のポスター・パンフレット

4) 医療関係者

5）家族・友人・知人 (医療関係者老除く)

6) 本

7）セミナー・講演

8) その他 (
） 9）特になし

・(治験についてもっと理解したいと答えた人) 治験について理解するためにどのようなことが知りたいです か?以下からあてはまるもの全て○で囲んで下さい。
1 ) 治験が必要な理由
2) 薬ができるまでの過程
3）インフォームド・コンセント
4) 病気が悪くなったときの対心
5) プラセボ (偽薬) が必要な理由
6）受けられる医療の内容
7) 具体的なメリット・デメリット
8）副作用時の対心
9) その他(

・(治験についての教育がもっと必要だと答えた人) どのような教育機会があれば良いと思いますか?

項目 III：治験に関する知識や教育状況

\section{1. 治験用語に関する知識}

治験に関する用語として選択肢から該当するものを選 んでもらい, 結果を図 6,7 にまとめた. 薬剤師と薬学 生の回答について検討を行ったところ，「ヘルシンキ宣 言 $\lrcorner\left(\right.$ Pearson $\left.の X^{2}=87.785, p<0.01\right),\ulcorner G C P\lrcorner($ Pearson $の$ $\left.X^{2}=62.676, p<0.01\right),\ulcorner I C H\lrcorner\left(\right.$ Pearson $X^{2}{ }^{2}=20.676, p$ $<0.01)$, 「標準業務手順書」(Pearson $の X^{2}=8.661, p<$ 0.01) $,\ulcorner I R B\lrcorner\left(\right.$ Pearson $\left.の X^{2}=6.566, p<0.05\right),\ulcorner\mathrm{CRC}\lrcorner$
(Pearson $\left.\mathrm{X}^{2}{ }^{2}=80.290, p<0.01\right)$, $\ulcorner$ 二重盲検試験 $\lrcorner($ Pearson $\left.の X^{2}=11.502, p<0.01\right)$ の各項目で学生のほうが有 意に「説明できる」と答えていた .

薬剂師の回答について言葉の知識と年齡との関連につ いて検討を行ったところ，年齢が高いほうが「ヘルシン キ宣言」(Pearsonの相関 $r=-0.364, p<0.01),\ulcorner G C P\lrcorner$ (Pearson $の$ 相関 $r=-0.264, p<0.05),\ulcorner I R B\lrcorner($ Pearson $の$ 相関 $r=-0.272, p<0.01),\ulcorner C R C\lrcorner($ Pearson の相関 $r=-$

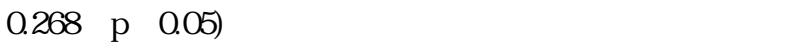


表 2 . 対象者背景

\begin{tabular}{|c|c|c|c|}
\hline \multirow{2}{*}{ 回収率 } & & 薬剤師 & 薬学部4年生 \\
\hline & & $91 / 140(65 \%)$ & $192 / 273(70 \%)$ \\
\hline 性別 & 性別 & $39(42.9 \%)$ & $60(31.3 \%)$ \\
\hline \multicolumn{2}{|c|}{ 女性 } & $52(57.1 \%)$ & $131(68.2 \%)$ \\
\hline \multicolumn{2}{|c|}{20 代 } & $26(29 \%)$ & - \\
\hline \multicolumn{2}{|c|}{30 代 } & $41(50 \%)$ & - \\
\hline \multicolumn{2}{|c|}{ 40代 } & $12(13 \%)$ & - \\
\hline \multicolumn{2}{|c|}{50 代 } & $8(9 \%)$ & - \\
\hline \multicolumn{2}{|c|}{60 代 } & $3(3 \%)$ & - \\
\hline \multicolumn{2}{|c|}{ 70代 } & $1(1 \%)$ & - \\
\hline \multirow[t]{3}{*}{ 被験者経 } & あり & $4(4 \%)$ & $9(4.4 \%)$ \\
\hline & なし & $86(95 \%)$ & $183(95.3 \%)$ \\
\hline & 無回答 & $1(1 \%)$ & - \\
\hline \multicolumn{4}{|c|}{$\begin{array}{l}\text { 学生時代の病院実習経 } \\
\text { 験(薬剂師のみ) }\end{array}$} \\
\hline \multicolumn{2}{|c|}{ あり } & $73(80 \%)$ & - \\
\hline \multicolumn{2}{|c|}{ なし } & $17(19 \%)$ & - \\
\hline \multicolumn{2}{|c|}{ 無回答 } & $1(1 \%)$ & - \\
\hline
\end{tabular}
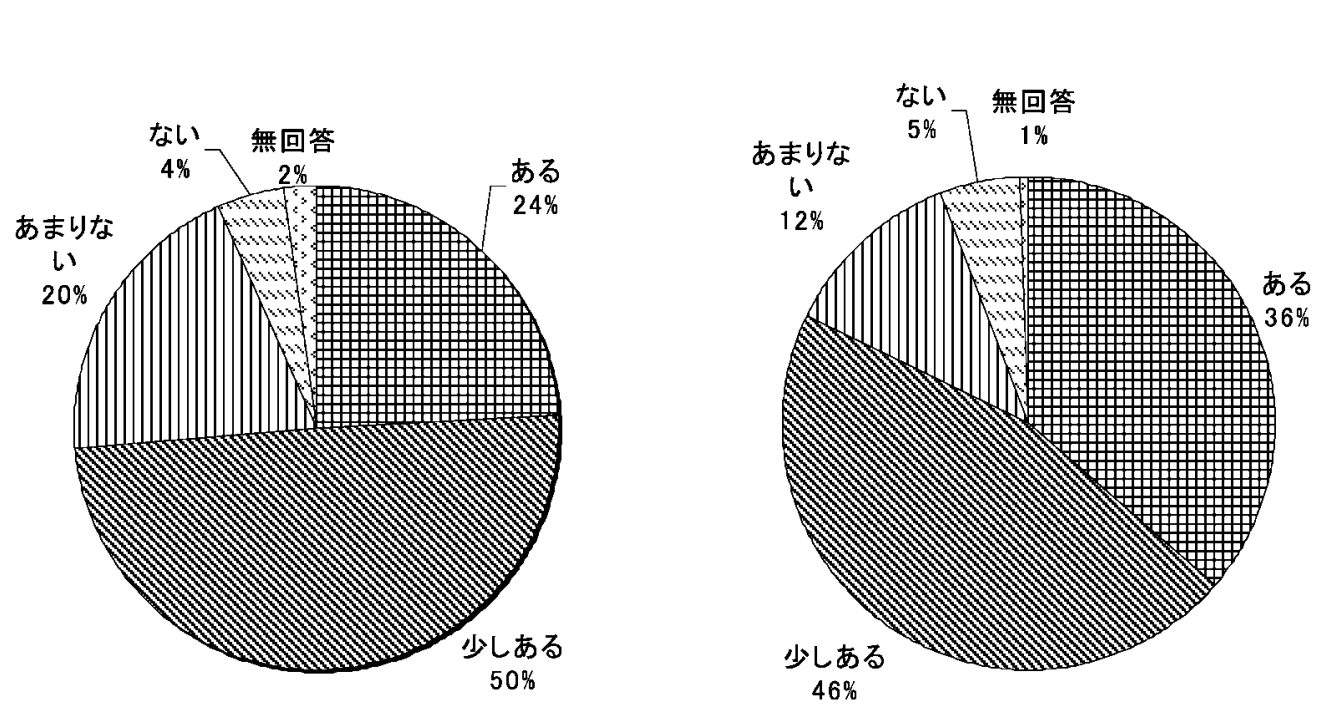

図 1 . 治験への関心

2. 治験に関する学習機会(薬斉師のみ)

薬斉師を対象として，学生時代に治験について学ゔ機 会の有無について選択肢から該当するものを一つ選んで もらった結果を図 8 にまとめた．学生時代に「学ら機会 がなかった」と答えた人が 35 名(38.5\%)おり，年代別に みると，20代では治験について大学時代「講義と実習」 で学んでいると答えた割合が高かった(Pearson のX ${ }^{2}=$ $34.495, p<0.05)$.

\section{3. 卒業後の治験に関する情報源(薬剂師のみ)}

卒業してから治験に関する情報源としていたものにつ いて, 選択肢の中から該当するものを選んでもらった結
果を図 9 にまとめた(複数回答可).「炎の他」として， 「社内で治験参加の募集があった」,「病院勤務時にかか わった」,「メーカーで開発に携わっていた」,「患者から 情報をもらった」などがあげられていた .

治験の情報源と年齢との関係について検討を行ったと ころ, 年齢が高いほうがマスメディア(Pearson の相関 $r$ $=0.261, \mathrm{p}<0.05)$, 本 (Pearson の相関 $r=0.402, p<0.01)$, セミナー・講演(Pearson の相関 $r=0.358, p<0.01)$ を情 報源と答えていた。

項目IV：今後の治験教育

1. 治験についてもっと理解したいか 


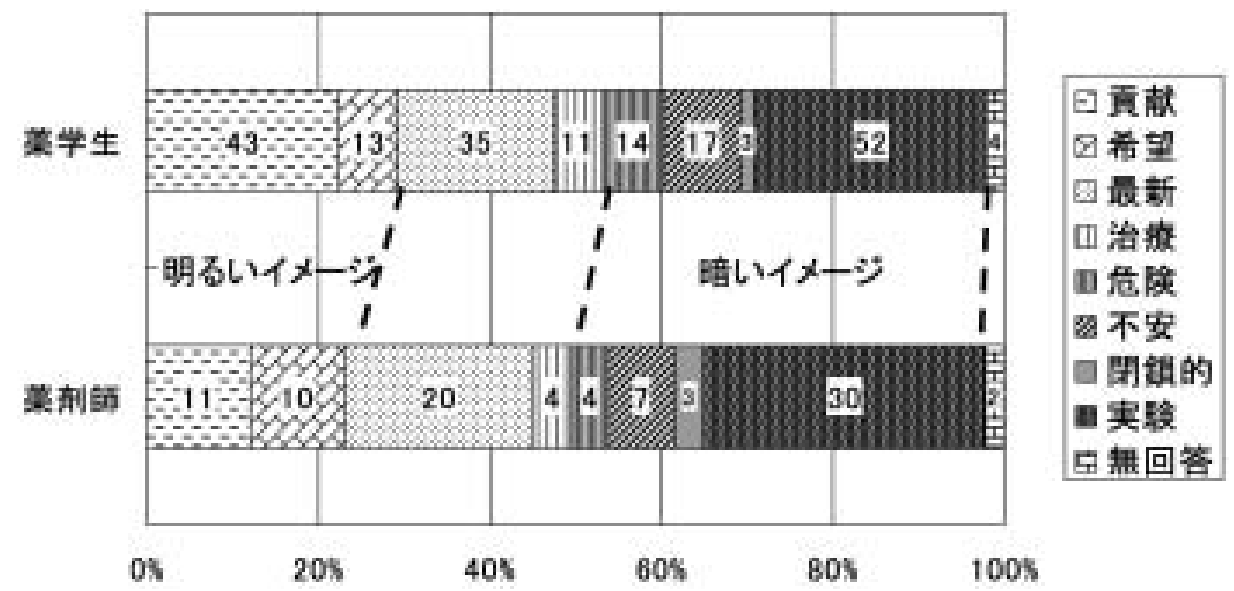

図 2 .「治験」から連想する言葉

薬剂師

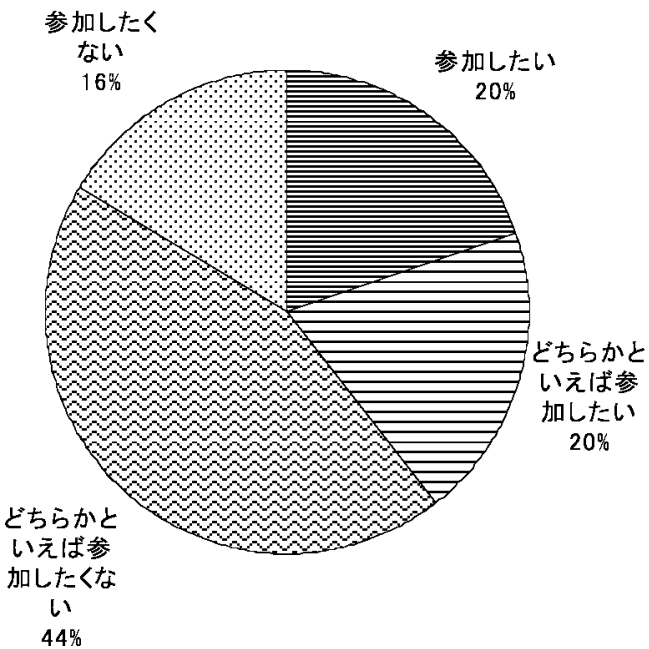

薬学生

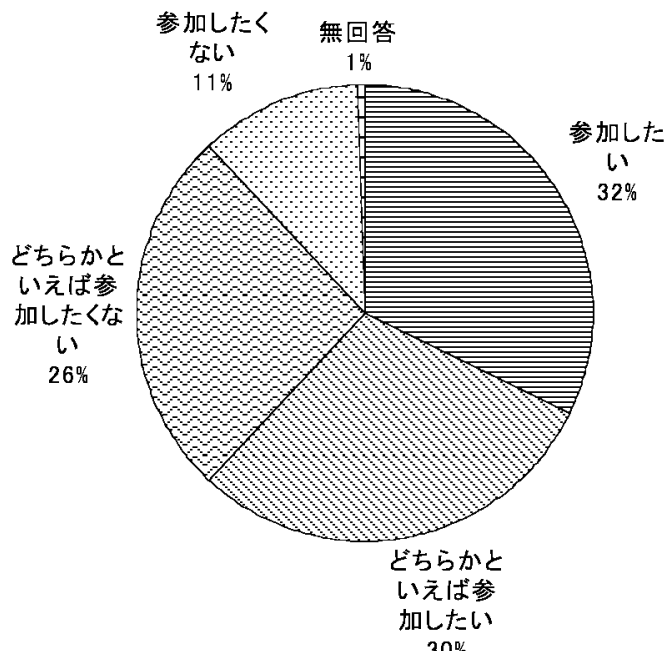

$30 \%$

図 3 . 治験への参加

「治験について今後もっと理解を深めたいか？」とい う問いに対して，薬闵師は「理解したい」81名(89.0\%)， 「理解したくない」9名(9.9\%), 無回答1名(1.1\%), 薬 学生は「理解したい」152名(79.2\%)，「理解したくない」 37 名 $(19.3 \%)$, 無回答 3 名 $(1.6 \%)$ となり，薬斉師は薬学 生に比して, 治験についてもっと理解したいと思ってい た(Pearson $\left.の X^{2}=4.80, p<0.05\right)$.

「もっと理解したい」と答えた人に選択肢から理解し たい内容を具体的に選んでもらった結果を表 $\mathbf{5}$ にまとめ た。弚の他」として，薬学生からは「医療人の患者へのか かわり方」、「安全な゙治験の選び方」などがあげられた . 薬斉師と薬学生の結果を比較したところ薬剤師は「治験 が必要な理由」(Pearson の $r=-0.191, p<0.01) 「$ 薬がで きるまでの過程」(Pearson の $r=-0.191, p<0.01)$ を治験 について理解したい内容としてより多くあげていた .
2. 薬学教育における治験関連教育

今後, 薬学教育における治験関連教育の必要性につい て, 薬剤師は「必要」78名(85.7\%)，「必要ではない」11 名(12.1\%), 無回答 2 名(2.2\%), 薬学生では,「必要」130 名(67.7\%)，「必要ではない」43名(22.4\%), 無回答 19 名(9.9\%)と, 薬阁師のほうか強く必要性を感じている結 果となった ·どのような教育機会があればよいかについ て自由に記述してもらったところ，薬剤師では，「実習・ 研修」,「実際に参加する」の他「CRC からの講義」, 「ネットを利用した講義」,「企業による勉強会」,「ビデ 才を見せる」など受け身型学習機会への要望が多く, 薬 学生では「現場を見学」,「CRCからの講義」、被験者 からの講義」,「MRによる講義」などの他「実習」,「実 際に参加する」,「ロールプレイ」など体験型学習の機会 への要望が多くあげられた . 

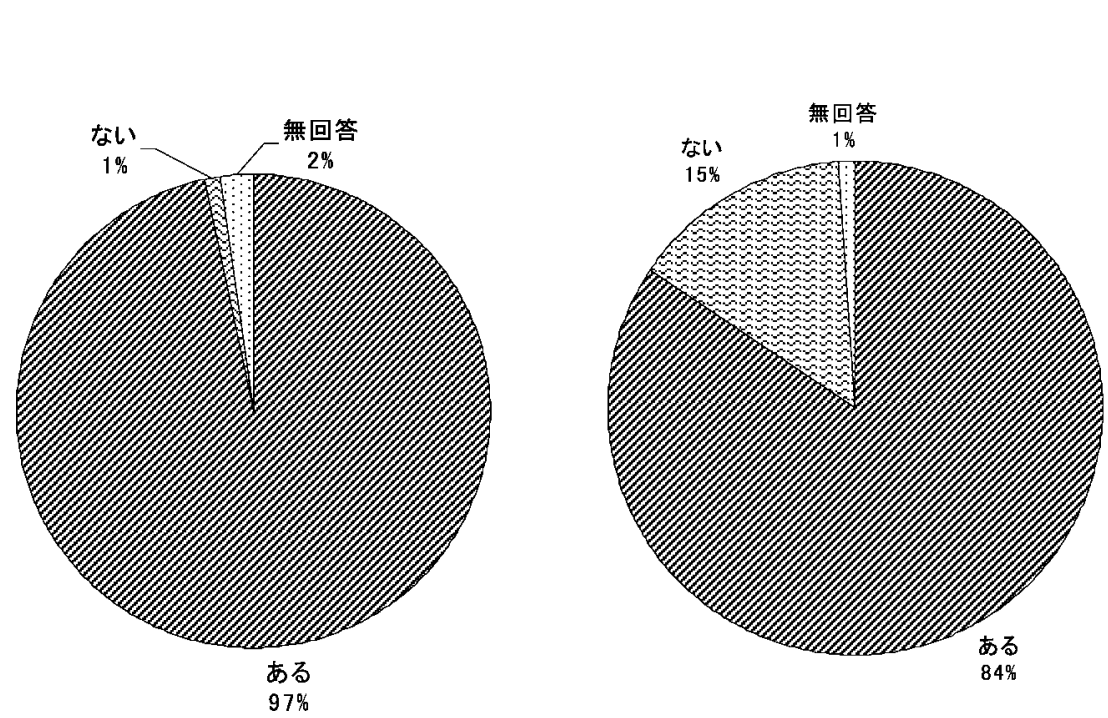

図 4 . 治験の参加に不安があるか

表 3 . 不安の内容(3つまで回答可)

\begin{tabular}{|c|c|c|}
\hline & 薬剤師 & 薬学生 \\
\hline 副作用 & $72(31.3 \%)$ & $146(33.8 \%)$ \\
\hline 健康被害の対応 & $56(24.3 \%)$ & $113(26.2 \%)$ \\
\hline スケジュール & $35(15.2 \%)$ & $64(14.8 \%)$ \\
\hline 治験薬の効き目 & $19(8.3 \%)$ & $24(5.6 \%)$ \\
\hline プラセボにあたる可能性 & $18(7.8 \%)$ & $24(5.6 \%)$ \\
\hline 治験をやめたい時の対応 & $13(5.6 \%)$ & $11(2.5 \%)$ \\
\hline 制約があること & $9(3.9 \%)$ & $21(4.9 \%)$ \\
\hline プライバシー保護 & $4(1.7 \%)$ & $8(1.9 \%)$ \\
\hline その他 & $4(1.7 \%)$ & $0(0 \%)$ \\
\hline
\end{tabular}

表 4 . 治験参加のメリット・デメリット

\begin{tabular}{|l|l|l|}
\hline \multicolumn{1}{|c|}{ メリツト } & \multicolumn{1}{|c|}{ 薬剤師 } & \multicolumn{1}{|c|}{ 薬学生 } \\
\hline 選択肢が増える & $56(61.5 \%) *$ & $46(24.0 \%)$ \\
\hline 社会の役に立つ & $25(27.5 \%)$ & $78(40.6 \%)$ \\
\hline $\begin{array}{l}\text { 手厚い医療が受 } \\
\text { けられる }\end{array}$ & $7(8 \%)$ & $12(6.3 \%)$ \\
\hline $\begin{array}{l}\text { 医療費が少なくて } \\
\text { 済む }\end{array}$ & $2(2 \%)$ & $6(3.1 \%)$ \\
\hline 協力費がもらえる & $1(1 \%)$ & $46(24.0 \%)$ \\
\hline $\begin{array}{l}\text { 待ち時間が少なく } \\
\text { て済む }\end{array}$ & $0(0 \%)$ & $1(0.5 \%)$ \\
\hline
\end{tabular}

\begin{tabular}{|l|l|l|}
\hline \multicolumn{1}{|c|}{ デメリット } & 薬剤師 & 薬学生 \\
\hline 副作用の心配 & $60(66 \%)$ & $\begin{array}{l}142 \\
(74.0 \%)\end{array}$ \\
\hline 細かい制限が多い & $14(15 \%)$ & $19(9.9 \%)$ \\
\hline プラセボの可能性 & $6(7 \%)$ & $9(4.7 \%)$ \\
\hline 定期的に病院に通う & $5(5.5 \%)$ & $13(6.8 \%)$ \\
\hline 治験を中止した後のこと & $5(5.5 \%)$ & $3(1.6 \%)$ \\
\hline その他 & $1(1 \%)$ & $1(0.5 \%)$ \\
\hline プライバシー保護 & $0(0 \%)$ & $1(0.5 \%)$ \\
\hline
\end{tabular}

* $p<0.05$ 

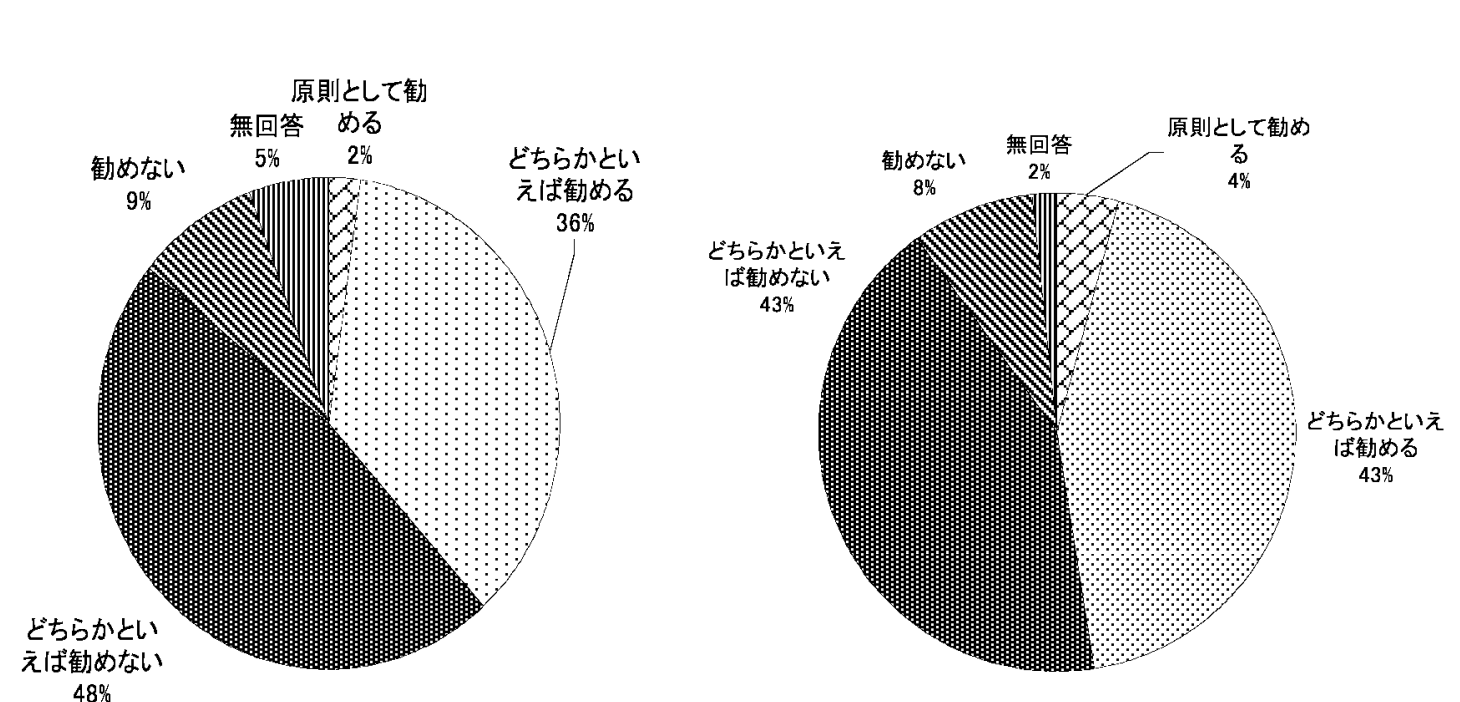

図 5 . 治験参加を相談された時の対応

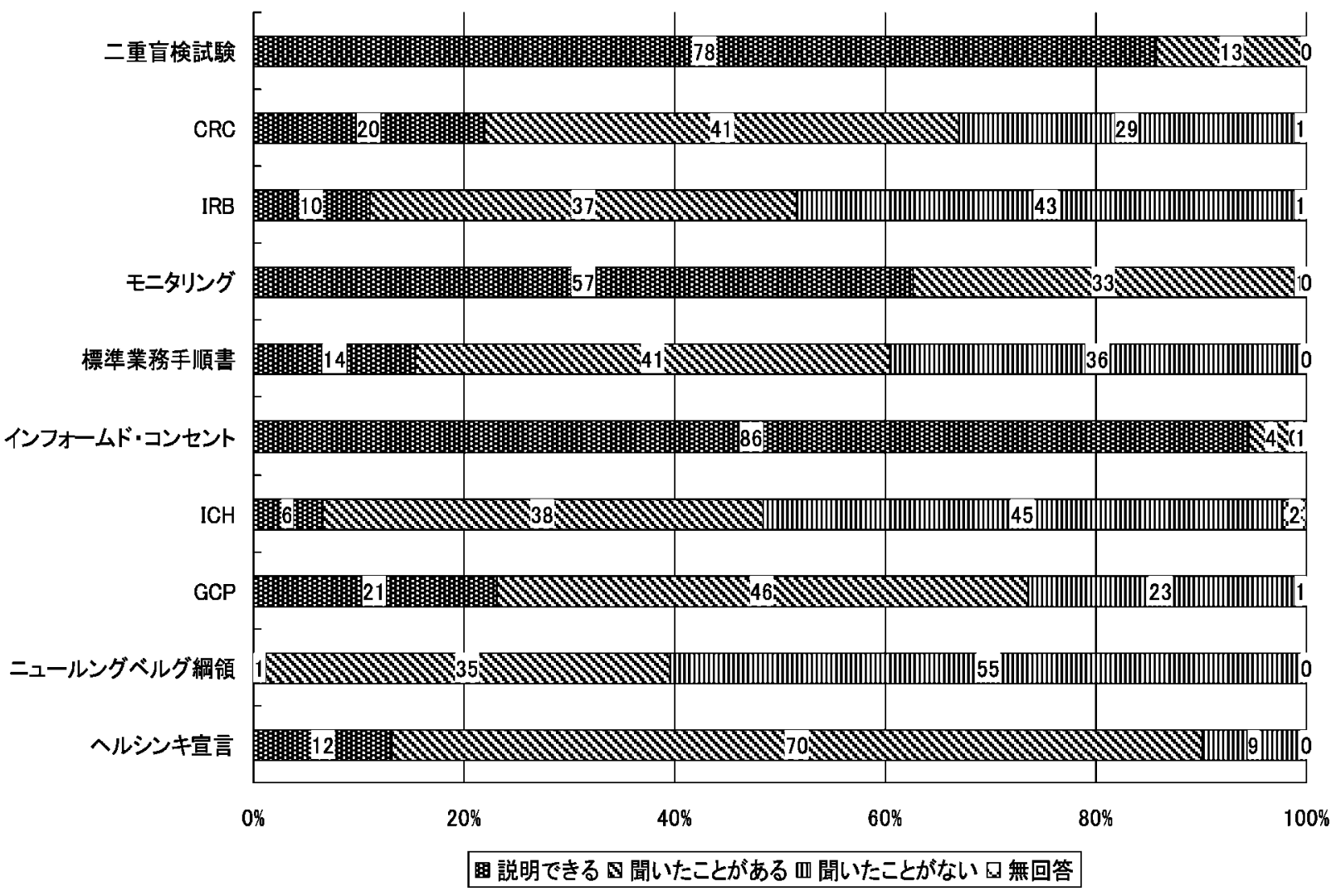

図 6 . 治験に関する言葉の知識(薬剂師)

考察

今回対象となった保險薬局薬剂師の中で自分自身が治 験の被験者として参加した経験を持つものは $4 \%$ に過ぎ ず，大半は治験に対して日常かかわる機会を持っていな かった .

福満らが 260 名の一般外来患者を対象に実施した治験

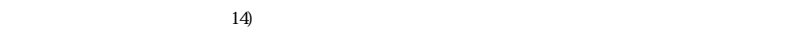

$\ulcorner$ 人体実験」，「副作用」などマイナスイメージのものは $52.0 \%$ ，「貢献」などプラスイメージのものは $35.1 \%$ あ げられており，どちらにも属しないもの $12.9 \%$ という 結果か報告されている．また，福長らによって行われた 患者を対象とした意識調査 ${ }^{15} て ゙ も ，$ 治験のイメージとし て「実験台にされる」38\%，「なんとなく怖い」22\% と いう結果が出ており，「治験」という言葉にマイナスイ メージを持たれがちな現状から，医療関係者には治験に 


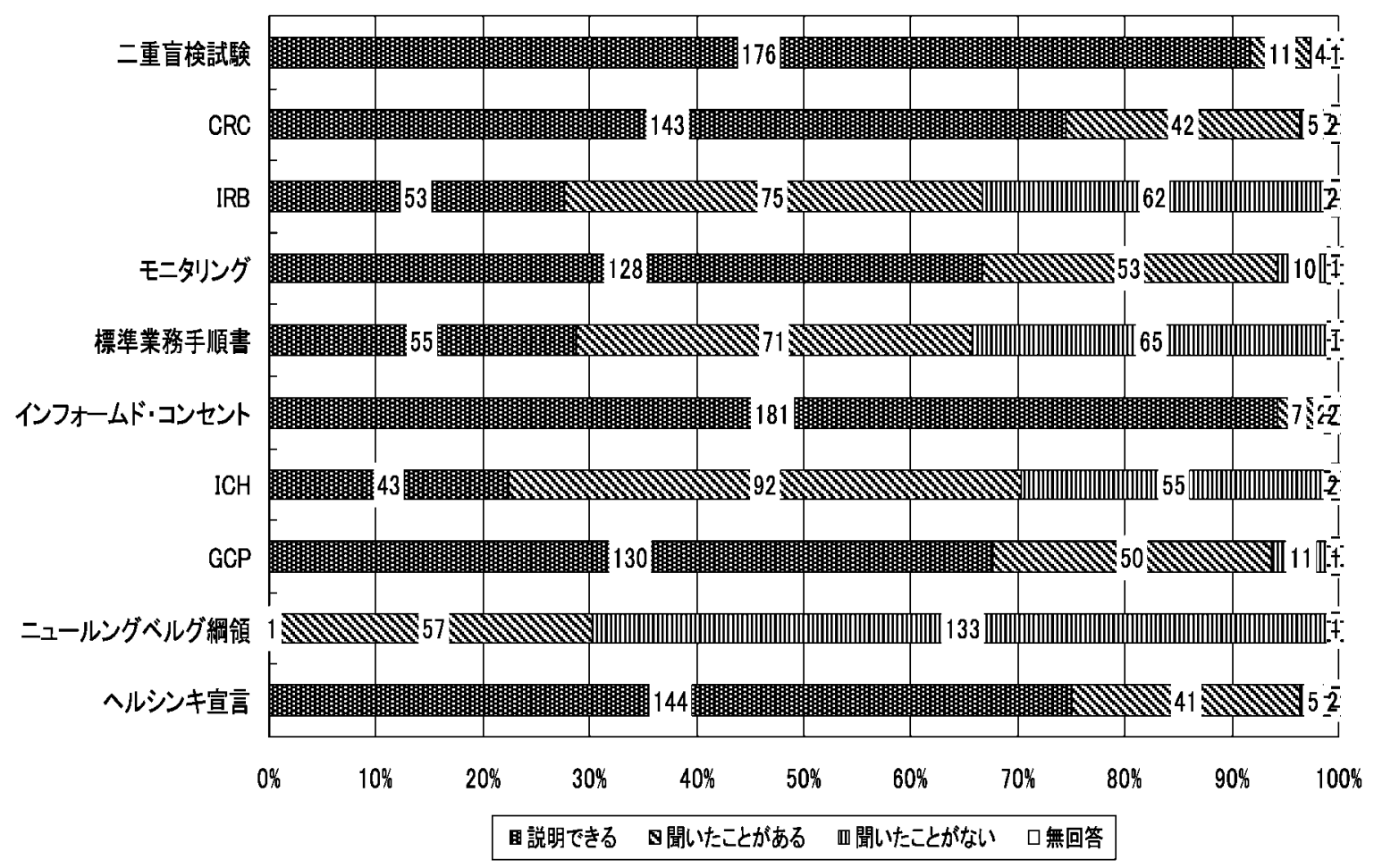

図 7 . 治験に関する言葉の知識(薬学生)

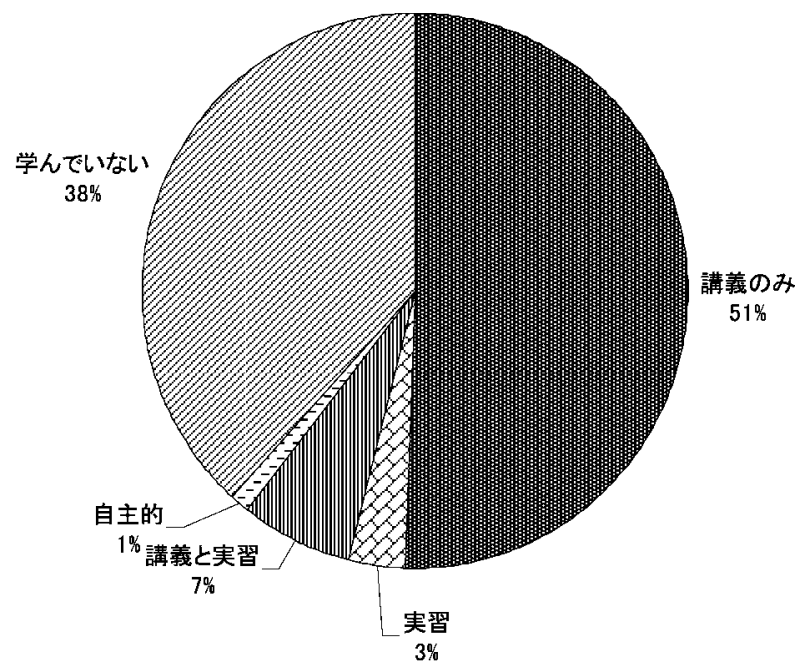

図 8 . 学生時代の治験学習機会(薬斉師)

対して正しく理解してもらう為の啓蒙的な役割が期待さ れている.しかし，今回のアンケート調査の結果から， 対象となった薬剂師は薬学生に比べて, 治験への関心は 低く, 治験への参加意欲が低く, 参加に対する不安も強 い傾向が明らかになった .

治験に参加するメリットとして，薬斉師があげたもの は「治療の選択肢が増える」が一番多く，薬学生では「社 会の役に立つ」が一番多くあげられていた . 薬学生は治 験から連想する言葉として「貢献」をあげる傾向も高く，
治験が社会貢献に結びつくという意識が高いと考えられ る. 兴の一方で薬学生は治験参加のメリットとして「協 力費」をあげたものが $24 \%$ おり，治験について健常ボ ランティアを対象とした第। 相のイメージか強く，治験 をバイト感覚にとらえている可能性が示唆された . 治験 に参加するデメリットについては，薬阂師も薬学生もと もに「副作用の心配」を一番多くあげ続いて「細かい制 限が多い」,「定期的に病院に通う」などをあげており， デメリットとして考えている内容に大きな差はなかった .

「患者や知人から治験への参加について相談されたと き参加を勧めるか」という問いに対して，「参加を勧め る」と答えた割合は薬斉師のほうが低かった，薬剂師が 理由としてあげたものには，「副作用の心配」のほか「自 分に十分な知識がないから」との答えも多かった .

これらのことから，治験に対して薬斉師が消極的であ る背景には, 治験に対する知識不足が影響している可能 性が考えられた。弚こで治験に関する知識を問うため に, 治験に関連する基本的な言葉をあげ説明できる」, 「聞いたことがある」,「聞いたことがない」の三段階で 答えてもらったところ，全体的に薬剤師のほうが「説明 できる」と答えた割合は少なかった . あげた言葉の中で も，「 「GCP」(75\%，24\%)と「CRC」(82\%，17\%)など薬学 生の $99 \%$ が「説明できる」または「聞いたことがある」 と答えている治験関連の言葉について，薬剤師は弚れ先 れ 26\%，34\%の人が「聞いたことがない」と答えてい た。 


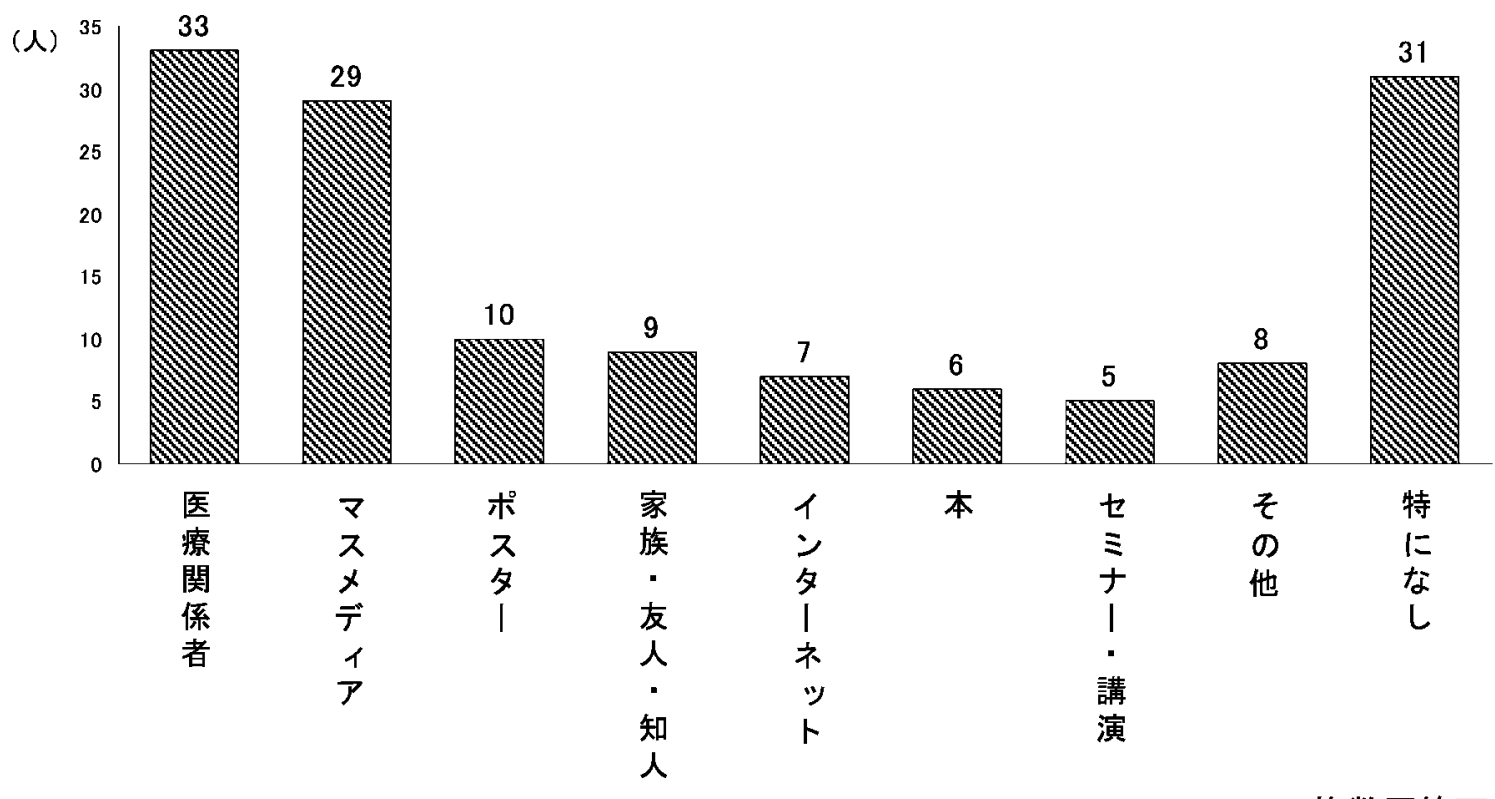

複数回答可

図 9 . 卒業後の治験に関する情報源(薬斉師)

表 5 . 治験について理解したい内容

\begin{tabular}{|c|c|c|}
\hline & 薬剂師 & 薬学生 \\
\hline メリット・デメリット & $61(20.5 \%)$ & $97(22.0 \%)$ \\
\hline 副作用の対応 & $61(20.5 \%)$ & $99(22.5 \%)$ \\
\hline 医療の内容 & $57(19.1 \%)$ & $74(16.8 \%)$ \\
\hline 悪くなつた時の対応 & $49(16.5 \%)$ & $83(18.9 \%)$ \\
\hline 治験が必要な理由 & $20(6.7 \%) * *$ & $24(5.5 \%)$ \\
\hline 薬ができるまでの過程 & $18(6.1 \%) * *$ & $23(5.2 \%)$ \\
\hline インフオームド・コンセント & $18(6.1 \%)$ & $21(4.8 \%)$ \\
\hline プラセボが必要な理由 & $8(2.7 \%)$ & $12(2.7 \%)$ \\
\hline その他 & $5(1.7 \%)$ & $7(1.6 \%)$ \\
\hline
\end{tabular}

${ }^{*} p<0.01$

$\langle そ の$ 他 $>$

薬剂師 : 実際に体験したい、治験の内容、治験にかかる費用、行われる頻度、治験の流れ 薬学生 : 医療人の患者への関わり方、安全な治験の選び方

対象となった保険薬局薬剂師の大学時代の治験関連教 育機会について聞いた結果でも，38\% が大学時代に治 験について学んだ機会は「ない」あるいは「覚えていな い」と答えており，「学んだ」と答えた中でもほとんど の人が「講義のみ」での教育を受けており，「病院実習 もあった」という人は少なかった．また，薬斉師が卒業 後影響を受けた情報源としては，「医療関係者」に続い て「マスメディア」などがあがっていたが，松村ら ${ }^{5} に$ よると治験の情報源として「新聞・杂隹誌・テレビなどの マスメディア」など一方通行の情報を受身で解釈した場
合, 治験に対して漠然とマイナスのイメージを抱く危険 性も指摘されている.

本調査で対象とした薬学生が , 治験に関して少なくと も講義の中では学んでおり, 病院実習においてもなんら かの教育機会を得ていることを考えあわせると，ここ数 年の薬学教育の中での治験に対する教育機会の変遷がう かがわれるとともに, 正しい知識や認識を得るための教 育機会の必要性が示唆された .

先に述べたように現在治験に関する政府の取り組みが 進んでいることも影響をしてか, 福長らが行った外来患 


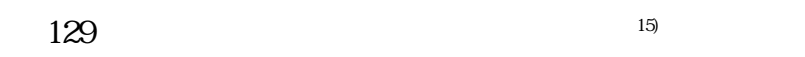
験という言葉を聞かれたことがありますか」という問い に対し $43 \%$ があると答えている．また，原田らが外来 患者 200 名を対象にして行った調査 9)では「治験につ いてもっと知りたい」と答えた患者が $74.1 \%$ おり，治 験への関心が高まっている気配がうかがわれる．今回調 査にこ協力いただいた薬局薬剤師の中にも，すでに「来 局患者から治験に関する相談を受けた経験がある」との 回答があり，今後一般の患者さんが保険薬局で治験参加 に対する相談をする機会の増加が予想される．

古川らが行った被験者に対する意識調査 ${ }^{12)}$ では，治験 参加への最大の動機は「医師の勧め」76\%であり，治 験参加理由は「医師の勧めを信頼」が $58 \%$ という結果 が得られている . 小林らが治験参加者を対象として行っ

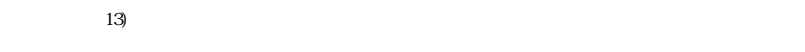
分の病気が良くなることへの期待」90.1\%，「医師から の説明に納得できた」49.8\%，「治験コーディネーター からの説明に納得できた」52.7\% などがあがっており， 医師や CRC からのインフォームド・コンセントが「理 解し納得できた」ことが参加を決めた大きな要因である ことが指摘されている.

治験参加を迷っている患者から相談を受けたときに， 根拠のある正確な情報提供を行い医療人として信頼関係 を構筑するためには，薬斉師自身が治験を正しく理解す る必要性がある.今後, 薬斉師自身が正しい情報を得, 患者への正確な情報提供を行えるような教育機会は重要 であると考える。

今後の治験教育に関する質問では, 薬斉師, 薬学生と もに「治験についてもっと理解したい」との答えが多 かった . 具体的に理解したい内容について選んでもらっ たところ，「治験が必要な理由」と「薬ができるまでの 過程」については薬阁師のほうか薬学生よりも「理解し たい内容」としてあげていた . 治験についての教育が学 部教育に取り入れられてきている時代の流れを考える と，これらの項目は治験に関する基本的な知識として現 場の薬剂師にも学習機会が与えられる必要がある．

薬学教育における今後の治験関連教育の必要性につい て聞いたところ, 薬剤師のほうが薬学生に比して「必 要」と答えた割合が高かった．また，教育機会について 具体的に記述してもらったところ，薬剤師では「CRC や企業による講演会」,「ビデオやネットを利用した講 義」など知識面を中心とした受け身の教育機会への要望 が強かったのに対し，薬学生では, $「 \mathrm{CRC}$, 被験者, MR からの講義」，「現場の見学」のほか，「ロールプレイ実 習」,「実際に参加」などより臨床現場に近いところで具 体的なことを学引機会へ期待が多く示された．

今回の結果からは, 現在 3，40 代以上の薬剤師は現在 の薬学生に比べて大学時代に治験に関する教育機会が少 なかったため, 基本的な知識が少なく参加意欲も低い傾 向が示唆された .一方で今後の治験関連教育に対しての
意欲は高く，薬学生への教育の充実はもとより，患者か らの相談を受ける機会の多い現場の薬斉師に対してもよ り充実した治験教育を提供する必要性と意義が明らかに なった 。

現在，当院治験管理室では, 病院実習薬学生を対象と し，e-ラーニングシステムを用いた治験に関する基本的 な講義, 治験同意説明のインフォームド・コンセント場 面を題材にした「ロールプレイ実習」などを行ってお り，CRCの初心者研修としての応用も試行中である . 今後，現場の薬剂師のニーズにあった，より実践的な教 育プログラムの構筑へ向けて検討を続け，治験教育とし て双方向性のある卒後教育の実現を目指していきたい．

謝辞 本調査を行うにあたり，ご協力いただきました保険 薬局の先生方に深く感謝いたします．

\section{引用文献}

1) 日本版新 GCP : 医薬品の臨床試験の実施の基準に関す る省令(平成 9 年厚生省令第 28 号)，官報(号外第 58 号) (1997).

2）厚生労働省・文部科学省「全国治験活性化 3 力年計画」 (2003).

3）文部科学省・厚生労働省「新たな治験活性化 5 力年計 画」(2007).

4) 有田悦子, 飯岡知美, 氏原淳, 大森亮子, 小柴聡美, 鎌 田里子, 東 慧子, 西島香, 多賀政晴, 岡本実穂, 厚 田幸一郎，医療人としてのコミュニケーション能力養 成プログラムに関する検討 - 治験における「同意説明 ロールプレイング実習」導入の試み一，医療薬学，34, 727-735 (2008).

5）松村真司，福原俊一, 黑川清, 臨床試験に関する一般市 民の全国意識調査，日本医事新報，3962，14-19 (2000).

6) 相澤篤, 柳田真悟, 加藤志歩奈, 横井利明, 大脇達也, 尾北香織, 高橋祐美子, 宮下司, 山竹卓宏, 山田滋久, 合田雅子, 治験推進を目的とした情報提供の現状と今後 について - 治験依頼者, 一般市民の立場からのアンケー 卜調査より一，臨床医薬，20, 1025-1043 (2004).

7) 内田治, 醍酯朝美, 成功するアンケート調査入門, 日本 経済新聞社, 1992.

8) 細谷未佳, 薬に対する意識と服薬行動に関する研究, Tokiwa J. Human Sci., 10, 65-75 (2000).

9）原田知実，森谷尚人，長谷川純一，三浦典正，佐野安希 子, 岸本洋輔, 大坪健司, 清水英治, 鳥取大学医学部付 属病院の外来患者および看護師の治験に対する認識，米 子医 . 55, 268-279 (2004).

10）小菅和仁, 鈴木真紀, 渡辺裕司, 橋本久邦, 大橋京一, 外来患者における治験に関する意識調査, 臨床薬理, 32, 177-178 (2001).

11) 安藤幸子, 安藤証子, 加藤経子, 治験説明に対する被験 者の理解度，日本看護研，26, 99-108 (2003).

12）古川裕之, 北川明, 工藤正純, 中尾泰史, 手島みどり, 山口辰哉，西原茂樹，比嘉保，手塚春樹，宮本謙一，中 
野真汎，被験者の治験に対する意識に関する多施設共同 調査の試み，臨床薬理，32, 183-184 (2001).

13) 小林真一, 柏熊留理子, 古川裕之, 松嶋由紀子, 中野重 行，倉成正恵，小野塚修二，安積織江，成田喜弘，治験 参加患者を対象とした調査，医薬産業政策研究所リサー チペーパー , 18, 9-10 (2004).
14) 福満香苗, 田口なるみ, 大塚ひとみ, アンケートにみる 治験の印象調査 - 看護師及び外来患者を対象として - , 臨床薬理, 35, 197 (2004).

15) 福長豊己, 池田博昭, 塚本秀利, 三嶋弘, 木平健治, 治 験に対する医師，患者，治験コーディネーターの意識調 査，臨床評価，32, 259-270 (2005). 